\title{
Extension of the core map of common bean with EST-SSR, RGA, AFLP, and putative functional markers
}

\author{
Luiz Ricardo Hanai · Luciane Santini · Luis Eduardo Aranha Camargo • \\ Maria Helena Pelegrinelli Fungaro $\cdot$ Paul Gepts · Siu Mui Tsai · \\ Maria Lucia Carneiro Vieira
}

Received: 26 February 2009/Accepted: 15 June 2009/Published online: 3 July 2009

(C) The Author(s) 2009. This article is published with open access at Springerlink.com

\begin{abstract}
Microsatellites and gene-derived markers are still underrepresented in the core molecular linkage map of common bean compared to other types of markers. In order to increase the density of the core map, a set of new markers were developed and mapped onto the RIL population derived from the 'BAT93' $\times$ 'Jalo EEP558' cross. The EST-SSR markers were first characterized using a set of 24 bean inbred lines. On average, the polymorphism information content was 0.40 and the mean number of alleles per locus was 2.7. In addition, AFLP and RGA markers based on the NBS-profiling method were developed and a subset of the mapped RGA was
\end{abstract}

L. R. Hanai · L. Santini - L. E. A. Camargo ·

M. L. C. Vieira $(\bowtie)$

Escola Superior de Agricultura "Luiz de Queiroz", Universidade de São Paulo, P.O. Box 9, Piracicaba, SP 13418-900, Brazil

e-mail: mlcvieir@esalq.usp.br

M. H. P. Fungaro

Centro de Ciências Biológicas, Universidade Estadual de Londrina, P.O. Box 6001, Londrina, PR 86055-900, Brazil

P. Gepts

Department of Plant Sciences, University of California, Davis, CA 95616, USA

\section{S. M. Tsai}

Centro de Energia Nuclear na Agricultura, Universidade de São Paulo, P.O. Box 96, Piracicaba, SP 13416-000, Brazil sequenced. With the integration of 282 new markers into the common bean core map, we were able to place markers with putative known function in some existing gaps including regions with QTL for resistance to anthracnose and rust. The distribution of the markers over 11 linkage groups is discussed and a newer version of the common bean core linkage map is proposed.

Keywords Phaseolus vulgaris · Core linkage map · EST-SSR · AFLP · NBS-profiling method ·

Resistance gene analogs

\section{Introduction}

Common bean (Phaseolus vulgaris L.) is the most important legume for direct human consumption in the developing world (Broughton et al. 2003). Production is especially important in Eastern and Southern Africa and Latin America where, in particular, rice and beans are an inseparable pair of staple foods for millions of people, representing a major source of dietary protein. Therefore, an increased effort has been devoted to improving bean varieties and expanding the area under bean cultivation. However, the productivity of most bean varieties grown in developing countries is still low.

Molecular markers have been used to assist common bean breeding programs in various ways (Jarne and Lagoda 1996), including studies on the 
origin and diversity of current cultivars (Gepts 1998), the domestication of $P$. vulgaris (Koinange et al. 1996), and the genetic control of resistance to important diseases (Miklas et al. 2003; Miklas et al. 2006a; Nodari et al. 1993b; Yu et al. 1998). The first molecular linkage maps of common bean were developed by means of restriction fragment length polymorphism (RFLP) markers (Adam-Blondon et al. 1994; Nodari et al. 1993a; Vallejos et al. 1992). Subsequently, common markers were used to integrate these maps by establishing the correspondence of their linkage groups (Freyre et al. 1998). For instance, a population of RILs derived from a cross between 'BAT93' and 'Jalo EEP558' was used as a core mapping population to construct an integrated linkage map. Although RFLP markers have been important to establish a genome-wide framework for anchoring and cross-referencing plant linkage maps, their widespread use in common bean was restricted by the lack of probes and the low-throughput nature of RFLP markers. Different types of markers, mainly random amplified polymorphic DNA (RAPD) were then used to increase the density of the common bean molecular linkage map (Freyre et al. 1998). More recently, single sequence repeats (SSR), also called microsatellites, have been developed and used to increase the density of existing maps, especially the core 'BAT93' $\times$ 'Jalo EEP558' linkage map (Blair et al. 2003; Grisi et al. 2007; Yu et al. 2000).

Currently, high-throughput markers, such as AFLP, are preferred for map saturation purposes. Putative functional markers are still underrepresented in the common bean molecular linkage map compared to other types of markers (López et al. 2003; Miklas et al. 2006b; Mutlu et al. 2006; Rivkin et al. 1999). Among these are resistance gene analogs (RGA), which are associated with a number of known $R$-genes (Brugmans et al. 2008; Ferrier-Cana et al. 2003; Kanazin et al. 1996; Mutlu et al. 2006) and quantitative resistance loci (Flandez-Galvez et al. 2003; Mutlu et al. 2006; Timmerman-Vaughan et al. 2002). In addition, microsatellites represent a limited proportion of the markers on the bean core map (Blair et al. 2003; Grisi et al. 2007; Yu et al. 2000), in spite of their many desirable attributes, including their presence in both non-genic and genic regions of plant genomes (reviewed by Li et al. 2004; Oliveira et al. 2006). A large number of unmapped microsatellite markers have been reported in the literature (Benchimol et al.
2007; Buso et al. 2006; Caixeta et al. 2005; Campos et al. 2007; Cardoso et al. 2008; Gaitán-Solís et al. 2002; Guerra-Sanz 2004; Hanai et al. 2007; Métais et al. 2002; Murray et al. 2002; Yaish and Pérez de la Vega 2003). In addition, the density of the common bean core map is still low for purposes of markerassisted selection and map-based cloning.

The objectives of the present work were to test new SSR markers developed from common bean expressed sequence tags (EST) in a set of $P$. vulgaris genotypes, assess their capacity to render SSR polymorphisms and to map them and other markers such as RGA and AFLP onto the common bean core map.

\section{Materials and methods}

\section{Plant material and DNA extraction}

A set of 23 common bean inbred lines and one accession of $P$. acutifolius were used to evaluate allelic variation at EST-SSR loci. Among P. vulgaris accessions, 17 genotypes belonged to the Mesoamerican gene pool ('Apetito Blanco', 'Baetão', 'Barbunya', 'BAT93', 'Brasi12', 'Carioca Comum', 'Flor de Mayo', 'Garbancillo', 'Great Northern', 'IAC-UNA', 'Jamapa', 'Mulatinho', 'Porrillo', 'Puebla152', 'Rio Tibagi', 'Sanilac' and 'Tu'), and six to the Andean gene pool ('Antioquia 8', 'CAL 143', 'Jabola', 'Jalo EEP558', 'Pompadour' and 'Red Kidney'). For map construction the inter-gene pool 'BAT93' $\times$ 'Jalo EEP558” population (Freyre et al. 1998; Nodari et al. 1993a) consisting of $74 \mathrm{~F}_{8}$ RILs was used.

Total genomic DNA was extracted from young leaf tissue using the CTAB extraction method as described by Doyle and Doyle (1987). DNA concentrations were estimated by electrophoresis on ethidium bromidestained agarose gels using appropriate molecular weight standards. From this quantification, aliquots at 10 and $50 \mathrm{ng} / \mu \mathrm{l}$ were prepared for EST-SSR amplifications and enzymatic digestions, respectively.

Development and amplification of EST-SSR markers

As reported previously (Hanai et al. 2007), a total of 3,126 bean EST sequences were obtained from the bean EST project homepage (http://lgm.esalq.usp.br/ BEST/). EST-containing SSR exhibiting at least five 
repeat units of di-, tri-, and tetranucleotide motifs were analyzed and 156 primer pairs were designed. PCR reactions were performed in a final volume of $16 \mu \mathrm{l}$ in 96-well plates using a Gen $\mathrm{Amp}^{\circledR}$ PCR System 9700 thermocycler (Applied Biosystems). Approximately $20 \mathrm{ng}$ of template DNA were mixed in a solution containing $0.2 \mu \mathrm{M}$ of both forward and reverse primers, $0.2 \mathrm{mM}$ of each dNTP, $1.5 \mathrm{mM} \mathrm{MgCl}_{2}, \quad 10 \mathrm{mM}$ Tris-HCl (pH 8.3), $50 \mathrm{mM} \mathrm{KCl}$ and 0.4 units Taq DNA polymerase (Promega). Four PCR program profiles were used to amplify EST-SSR loci. All four profiles started with a preliminary denaturation step at $94^{\circ} \mathrm{C}$ for 2 min followed by two stages. In both stages, denaturing and elongation conditions were held constant at $94^{\circ} \mathrm{C}$ for $30 \mathrm{~s}$ and $72^{\circ} \mathrm{C}$ for $60 \mathrm{~s}$, respectively. The duration of primer annealing was $45 \mathrm{~s}$, but the temperature varied in stage 1 , decreasing $1^{\circ} \mathrm{C}$ per cycle during 12 cycles $\left(65-53^{\circ} \mathrm{C}\right), 0.5^{\circ} \mathrm{C}$ per cycle during 10 cycles $(55-$ $\left.50^{\circ} \mathrm{C}\right)$ or $1{ }^{\circ} \mathrm{C}$ per cycle during 10 cycles $\left(55-45^{\circ} \mathrm{C}\right)$ in programs 1,2 and 3 , respectively. In program 4 , the initial annealing temperature was $45^{\circ} \mathrm{C}$ and increased $1^{\circ} \mathrm{C}$ per cycle during 10 cycles $\left(45-55^{\circ} \mathrm{C}\right)$. Stage 2 comprised 25 cycles of amplification. In all programs, the annealing temperature of stage 2 was the one reached at the end of the first PCR stage. Final elongation was performed at $72^{\circ} \mathrm{C}$ for $7 \mathrm{~min}$.

Development and sequencing of RGA markers

RGA markers were amplified based on the NBSprofiling methodology (van der Linden et al. 2004). This methodology is based on the digestion of DNA, ligation with adapters, and a PCR reaction where one primer targets the adapter while the other, which is degenerate, targets the conserved nucleotide binding site (NBS) domain of plant disease resistance genes.
This amplification results in several fragments per reaction due to the abundance of resistance gene-like sequences in plant genomes.

About $200 \mathrm{ng}$ of genomic DNA from the parental line 'BAT93' and 'Jalo EEP558' were digested with $R s a \mathrm{I}$ (New England BioLabs). Digestions were performed in a final volume of $20 \mu \mathrm{l}$ using $6 \mathrm{U}$ of the enzyme according to the manufacturer's recommendations, during $4 \mathrm{~h}$ at $37^{\circ} \mathrm{C}$. Reactions were terminated by heat inactivation $\left(20 \mathrm{~min}\right.$ at $\left.65^{\circ} \mathrm{C}\right)$. An adapter previously prepared from an equimolar mixture of LA (long arm) oligonucleotide (5'-ACTCGATTCTCAA CCCGAAAGTATAGATCCCA- $3^{\prime}$ ) and SA (short arm) oligonucleotide ( $5^{\prime}$-TGGGATCTATACTT*-3') was ligated to the restriction fragment ends. The $3^{\prime}$ end of the SA oligonucleotide was blocked for Taq DNA polymerase extension by the addition of an amino group (*). Ligation was performed by adding $20 \mu \mathrm{l}$ of a mixture containing $1.25 \mu \mathrm{M}$ adapter, $1 \times$ ligation buffer (New England BioLabs), 80 units T4 DNA ligase (400 units/ $\mu \mathrm{l}$; New England BioLabs) to $20 \mu \mathrm{l}$ of digested DNA. The reaction was incubated at $16^{\circ} \mathrm{C}$ overnight and terminated by heat inactivation $\left(65^{\circ} \mathrm{C}\right.$ for $10 \mathrm{~min})$. As template DNA $3 \mu \mathrm{l}$ of ligation products were used for the amplification of selected fragments anchored to the NBS-domain. For this, an AP (adapter primer) complementary to the adaptor $\left(5^{\prime}\right.$ ACTCGATTCTCAACCCGAAAG- $3^{\prime}$ ) and one of four NBS-primer were used in distinct reactions (Table 1). The amplification was performed in a final volume of $20 \mu \mathrm{l}$ containing $0.25 \mu \mathrm{M}$ of both primers, $0.2 \mathrm{mM}$ of each dNTP, $1.5 \mathrm{mM} \mathrm{MgCl}_{2}, 10 \mathrm{mM}$ Tris$\mathrm{HCl}(\mathrm{pH} 8.3), 50 \mathrm{mM} \mathrm{KCl}$ and 1.0 unit Taq DNA polymerase (Promega). The amplification was carried out in a Gen Amp ${ }^{\circledR}$ PCR System 9700 thermocycler (Applied Biosystems). A two-stage PCR was used after an initial denaturing step at $94^{\circ} \mathrm{C}$ for $5 \mathrm{~min}$. The first

Table 1 Designation and sequence of primers used to generate RGA markers based on the NBS-profiling method

\begin{tabular}{lll}
\hline Primer designation $^{\mathrm{a}}$ & ${\text { Sequence } 5^{\prime}-3^{\prime}}^{\prime}$ & Protein domain/motif \\
\hline AP & ACTCGATTCTCAACCCGAAAG & Adapter $^{\mathrm{b}}$ \\
NBSa-F & GGAATGGGKGGACTYGGYAARAC & NBS/kinase \\
Kdc-F & ATGGGAAGGAAGTATTCCAA & NBS/kinase \\
Kdc-R & ARGTTCCACAGGACATCACC & NBS/kinase \\
RGP-F & GGNATGGGYGGBRTHGGYAARAC & NBS/hydrophobic \\
\hline
\end{tabular}

\footnotetext{
${ }^{\mathrm{a}} \mathrm{F}$ for forward and $\mathrm{R}$ for reverse

b Primer specific to the adapter sequence used in combination with RGA specific primers
} 
stage consisted of 8 cycles at $94^{\circ} \mathrm{C}$ for $45 \mathrm{~s}$, at $58^{\circ} \mathrm{C}$ ($1^{\circ} \mathrm{C}$ per cycle) for $1 \mathrm{~min}$, and at $72^{\circ} \mathrm{C}$ for $1 \mathrm{~min}$, whereas the second stage consisted of 25 cycles at $94^{\circ} \mathrm{C}$ for $45 \mathrm{~s}, 50^{\circ} \mathrm{C}$ for $1 \mathrm{~min}$ and $72^{\circ} \mathrm{C}$ for $1 \mathrm{~min}$. A final extension of $7 \mathrm{~min}$ at $72^{\circ} \mathrm{C}$ was conducted. The amplification of fragments anchored to NBS-domain was assured by designing an adapter that does not have an AP-primer annealing site in the SA oligonucleotide. This annealing site is constructed after elongation of the NBS-primer, when the end of LA oligonucleotide is used as template for AP-primer annealing (for details see van der Linden et al. 2004).

RGA markers of interest were excised from polyacrylamide gels and reamplified following the same PCR conditions initially used. Fragments were resolved on agarose gels, purified (PCR purification kit, Qiagen), and cloned into pGEM $^{\circledR}-\mathrm{T}$ Easy vector (Promega) for sequencing. Inserts were sequenced in the forward and reverse directions. The sequencing reaction was performed as described by Sanger et al. (1977) using DYEnamic ${ }^{\mathrm{TM}}$ ET dye Terminator Cycle Sequencing Kit (Amersham Pharmacia Biotech, Inc.) on MegaBACE 1000 (Amersham Biosciences). Sequences were assembled using the Phred/Phrap/ Consed package using a phred score $\geq 20$ as the threshold for base quality. Nucleotide sequences were compared to sequences deposited in the Genbank database (http://ncbi.nlm.nih.gov/BLAST) using the BLAST tool (Altschul et al. 1990).

Generation of AFLP markers

AFLP markers were amplified based on the protocol described by Vos et al. (1995) with modifications. Restriction and ligation enzymes required for AFLP analysis were obtained from the New England Biolabs Company. Briefly, $200 \mathrm{ng}$ of genomic DNA from each of the parents and the $74 \mathrm{~F}_{8}$ RILs were double digested with EcoRI and MseI or Pst I and MseI enzymes (5 $\mathrm{U}$ of each) in a $25 \mu \mathrm{l}$ reaction mixture (10 mM Tris-acetate, pH 7.5; $10 \mathrm{mM} \mathrm{Mg-acetate,}$ $50 \mathrm{mM} \mathrm{K}$-acetate) during $4 \mathrm{~h}$ at $37^{\circ} \mathrm{C}$. All resulting fragments were ligated to adapter sequences by adding an equal volume of a ligation solution i.e. $30 \mathrm{mM}$ of Tris- $\mathrm{HCl}\left(\mathrm{pH} \mathrm{7.5),} 10 \mathrm{mM}\right.$ of $\mathrm{MgCl}_{2}$, $10 \mathrm{mM}$ of DTT, $1.0 \mathrm{mM}$ of ATP, $0.25 \mu \mathrm{M}$ of EcoRI or Pst I adapter, $2.5 \mu \mathrm{M}$ of $M s e \mathrm{I}$ adapter, and 80 units of T4 DNA ligase (400 units/ $\mu \mathrm{l}$ ). These reactions were incubated at $16^{\circ} \mathrm{C}$ overnight and terminated by heat inactivation $\left(65^{\circ} \mathrm{C}\right.$ for $\left.10 \mathrm{~min}\right)$. The adapter-ligated DNA $(3 \mu \mathrm{l})$ was used for the pre-selective amplification using AFLP primers based on the sequence of the EcoRI or PstI and MseI adapters, with one selective nucleotide at the $3^{\prime}$ end. The pre-selective reaction was amplified using the following conditions: $94^{\circ} \mathrm{C}$ for $2 \mathrm{~min} ; 26$ cycles of $94^{\circ} \mathrm{C}$ for $60 \mathrm{~s}, 56^{\circ} \mathrm{C}$ for $60 \mathrm{~s}$, $72^{\circ} \mathrm{C}$ for $60 \mathrm{~s}$; and a final elongation at $72^{\circ} \mathrm{C}$ for 5 min. Five microliters of a 10 -fold diluted preselected PCR product were used as DNA template for the selective amplification using AFLP primers with three additional selective nucleotides at the $3^{\prime}$ end. The following cycling parameters were used for selective amplification: $94^{\circ} \mathrm{C}$ for $2 \mathrm{~min} ; 12$ cycles of $94^{\circ} \mathrm{C}$ for $30 \mathrm{~s}, 65^{\circ} \mathrm{C}$ for $30 \mathrm{~s}, 72^{\circ} \mathrm{C}$ for $60 \mathrm{~s} ; 23$ cycles of $94^{\circ} \mathrm{C}$ for $30 \mathrm{~s}, 65^{\circ} \mathrm{C}$ for $30 \mathrm{~s}, 72^{\circ} \mathrm{C}$ for $60 \mathrm{~s}$; and a final elongation at $72^{\circ} \mathrm{C}$ for $5 \mathrm{~min}$.

\section{Genotyping}

All markers were resolved in 6\% w/v denaturing polyacrylamide gels (19:1; acrylamide:bis-acrylamide) using the electrophoresis apparatus Sequi-Gen ${ }^{\circledR}$ GT (Bio-Rad). Samples ( $3 \mu \mathrm{l})$ of amplified products were denatured with $1 \times$ loading buffer $(0.2 \%$ each bromophenol blue and xylene cyanol, 10 mM EDTA, $\mathrm{pH} 8.0$, and $95 \%$ formamide) at $95^{\circ} \mathrm{C}$ for 5 min before they were loaded onto the gels. The EST-SSR markers were electrophoresed for $2 \mathrm{~h} 30 \mathrm{~min}$ at $70 \mathrm{~W}$, and AFLP and RGA markers for $4 \mathrm{~h} 30 \mathrm{~min}$ at $80 \mathrm{~W}$. The loci were visualized by silver staining according to Creste et al. (2001). AFLP loci were coded using the name of the primer pair followed by the fragment size (bp). RGA loci were coded using the initials of the enzyme and NBS primer names followed by the fragment size (bp). The codes for EST-SSR markers are shown in Table 2.

\section{Map construction}

The segregation of each AFLP and RGA locus was scored by the presence or absence of the fragment. EST-SSR as well as rare codominant AFLP loci were scored by identifying the parental fragments in the segregating population. Goodness-of-fit tests for 1:1 segregation ratio were performed for all makers segregating in the $74 \mathrm{~F}_{8}$ RILs.

For the construction of the map, we adopted the following approach using the software MAPMAKER 


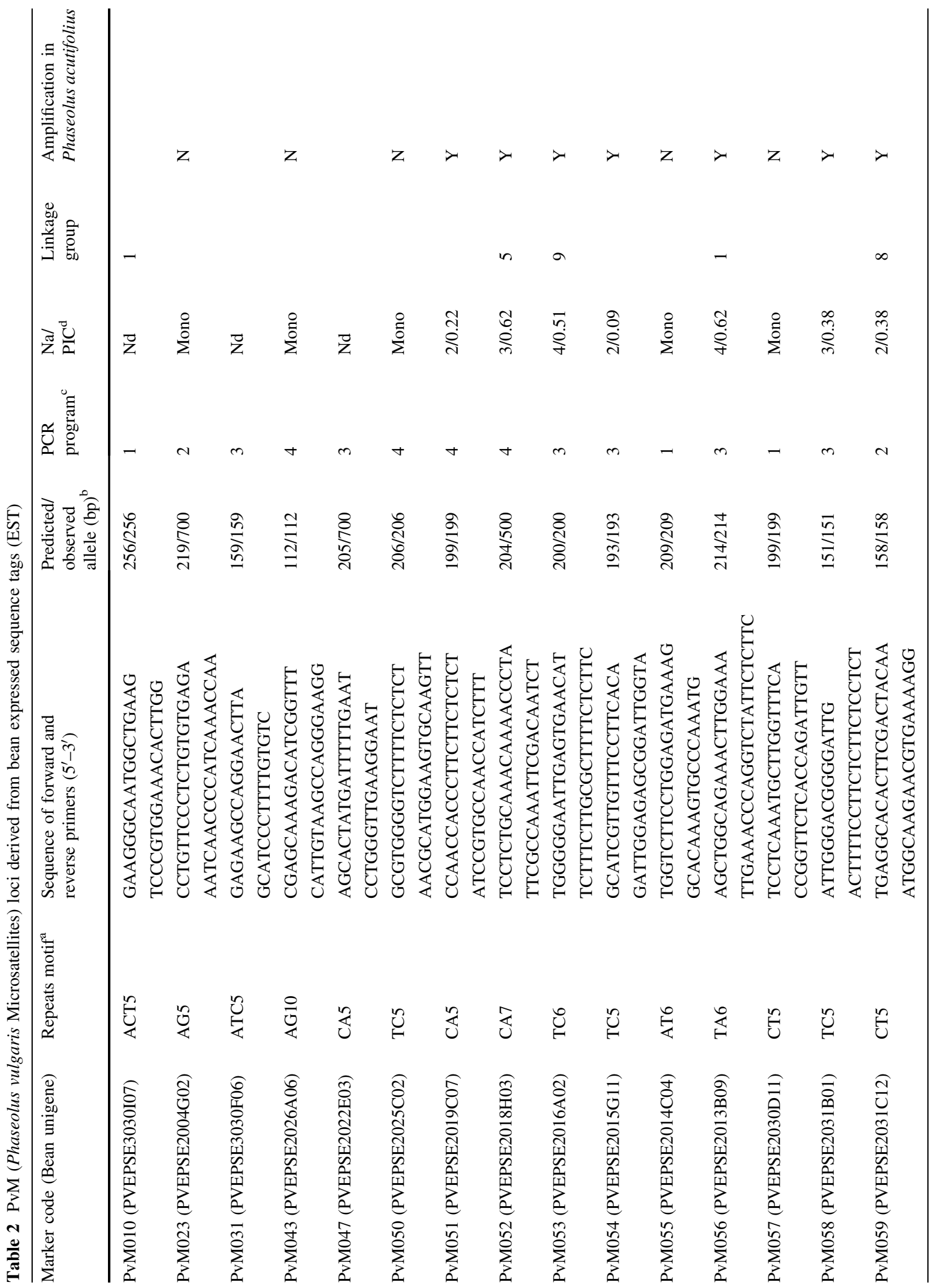




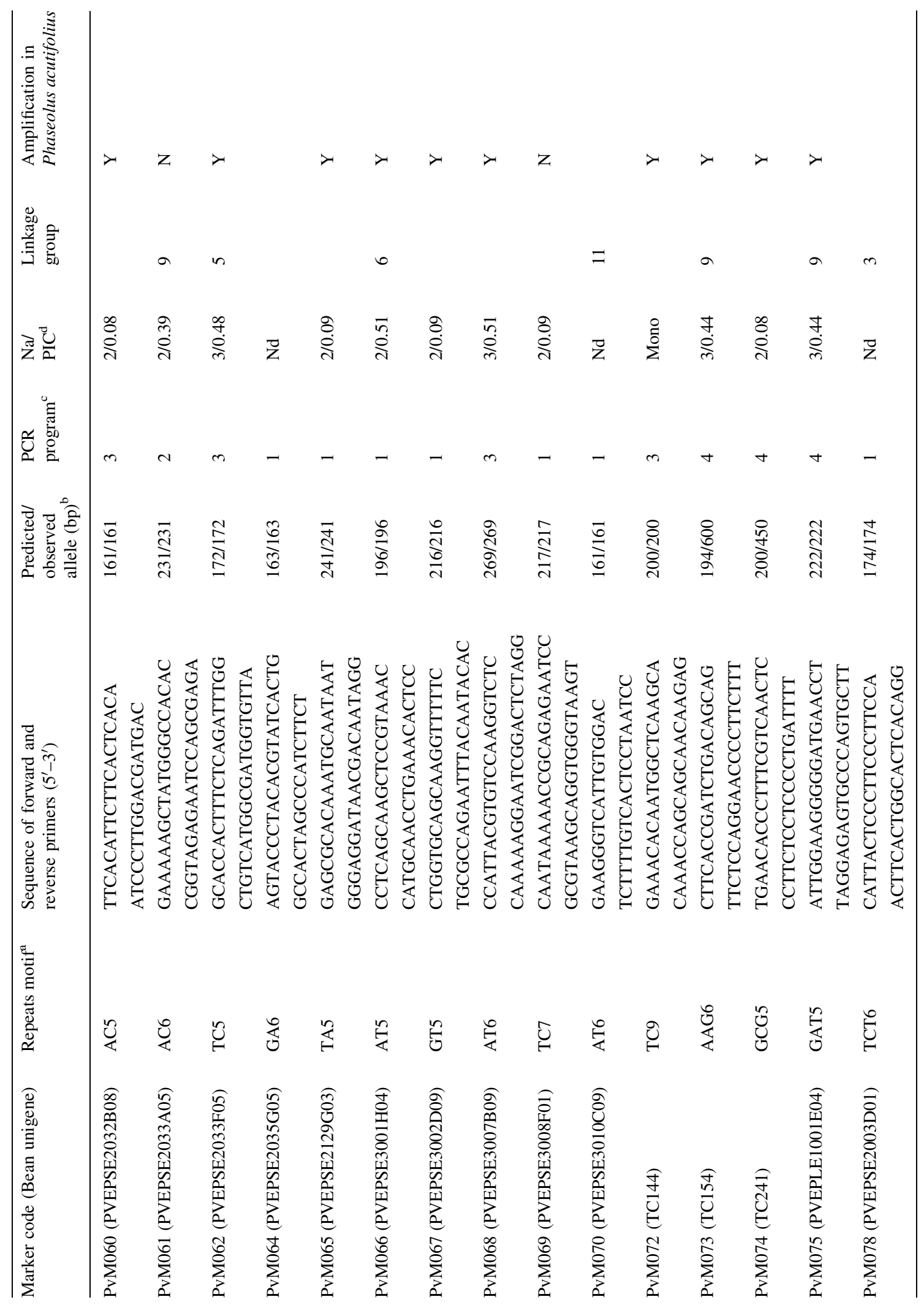




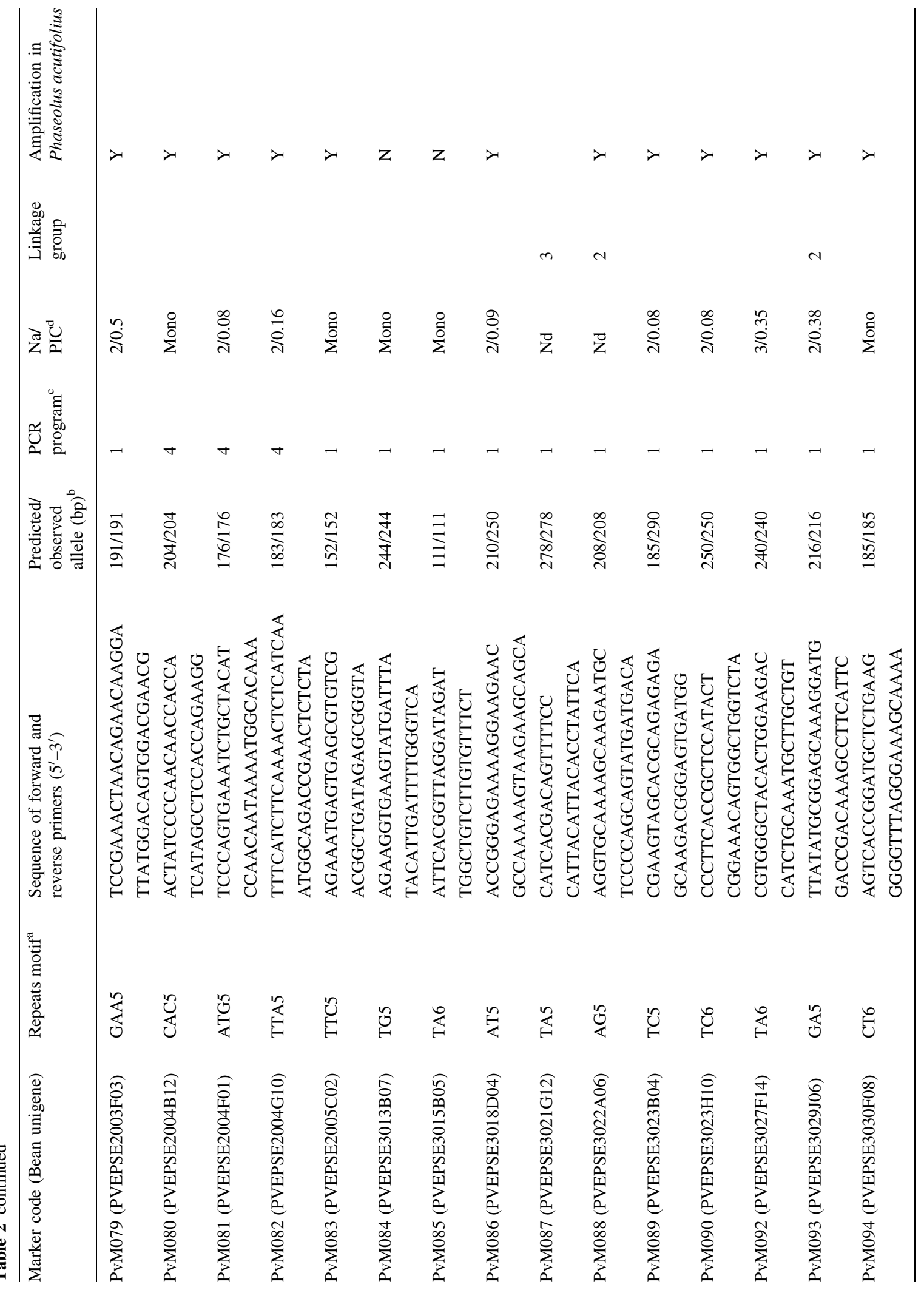




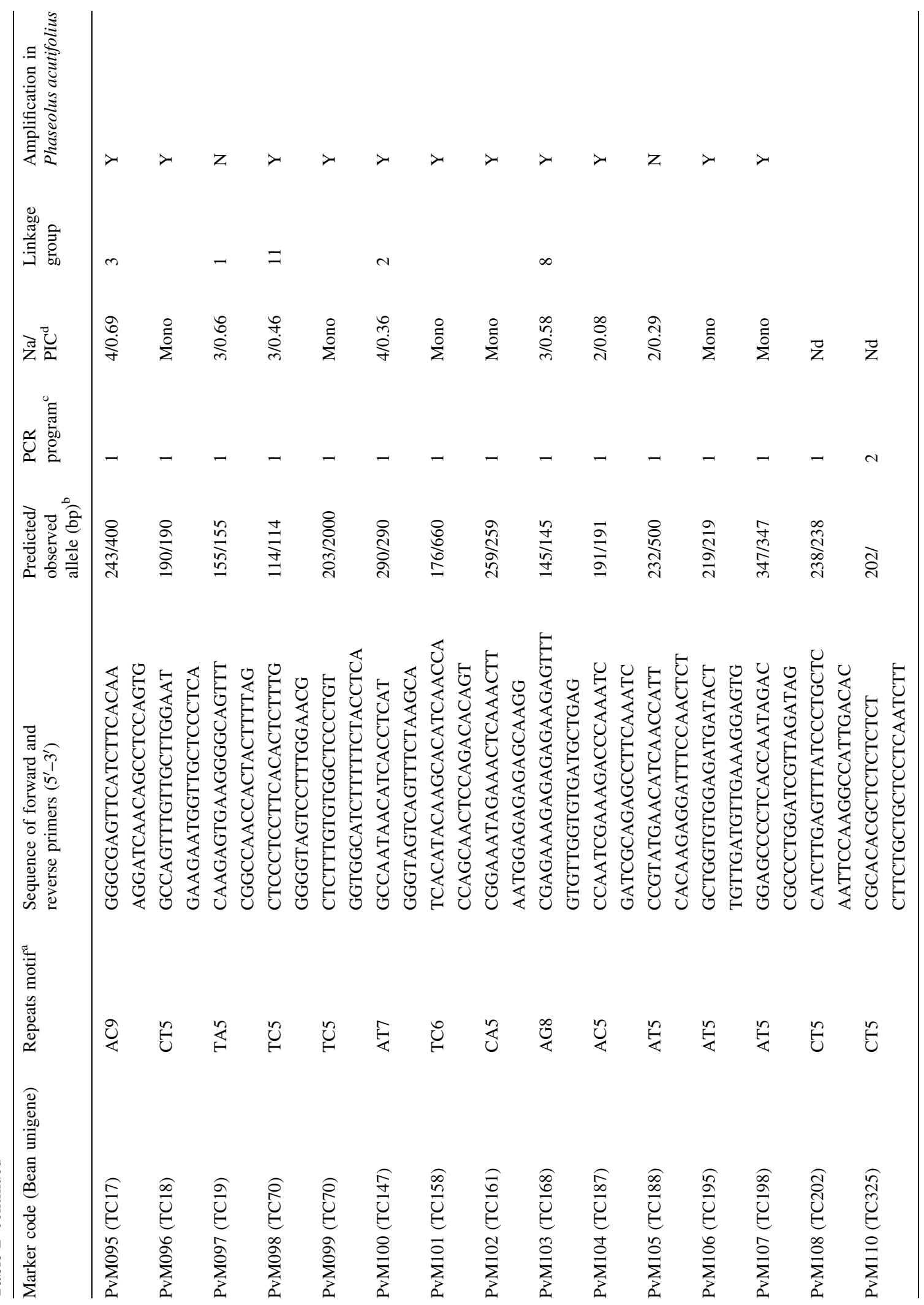




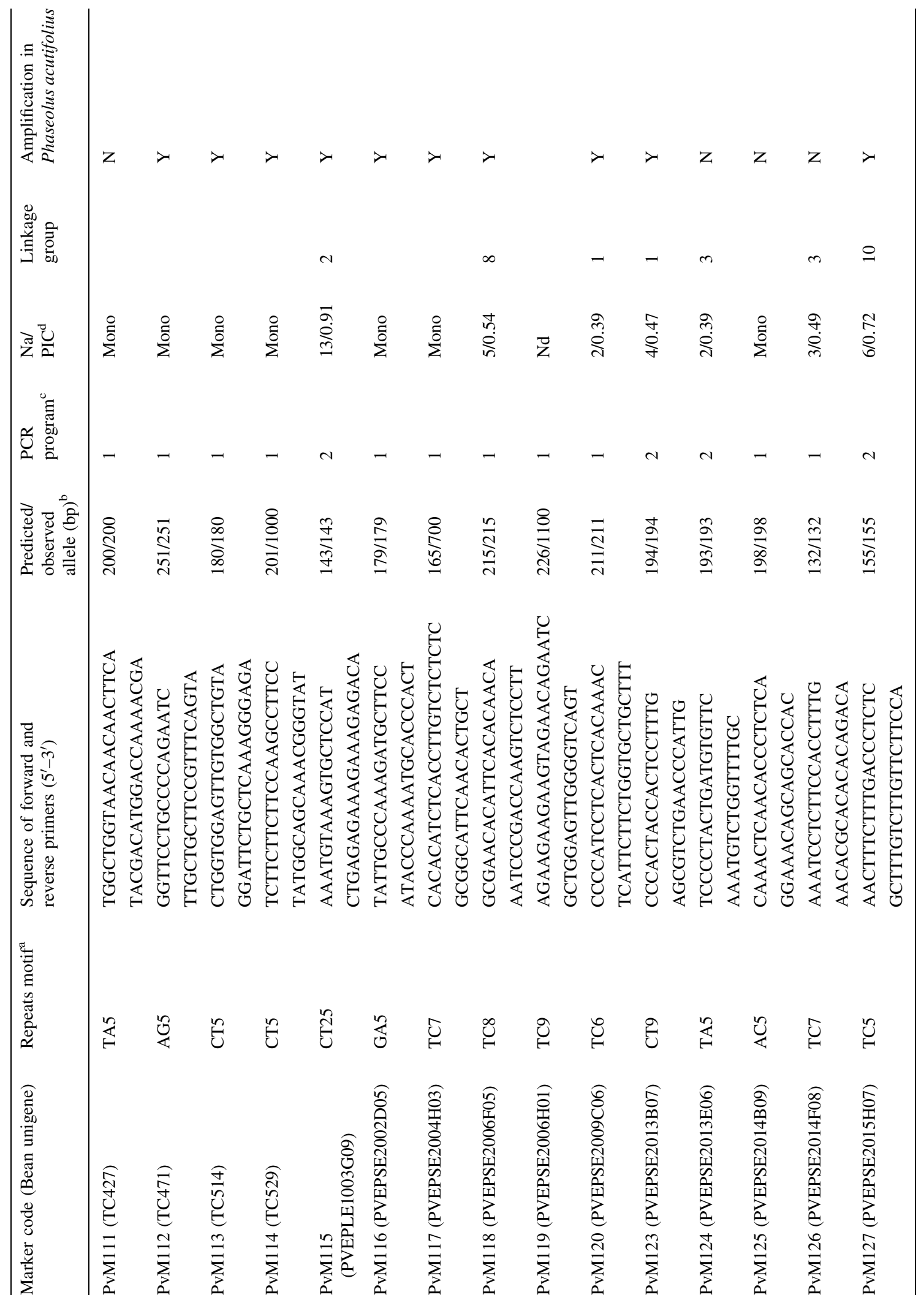




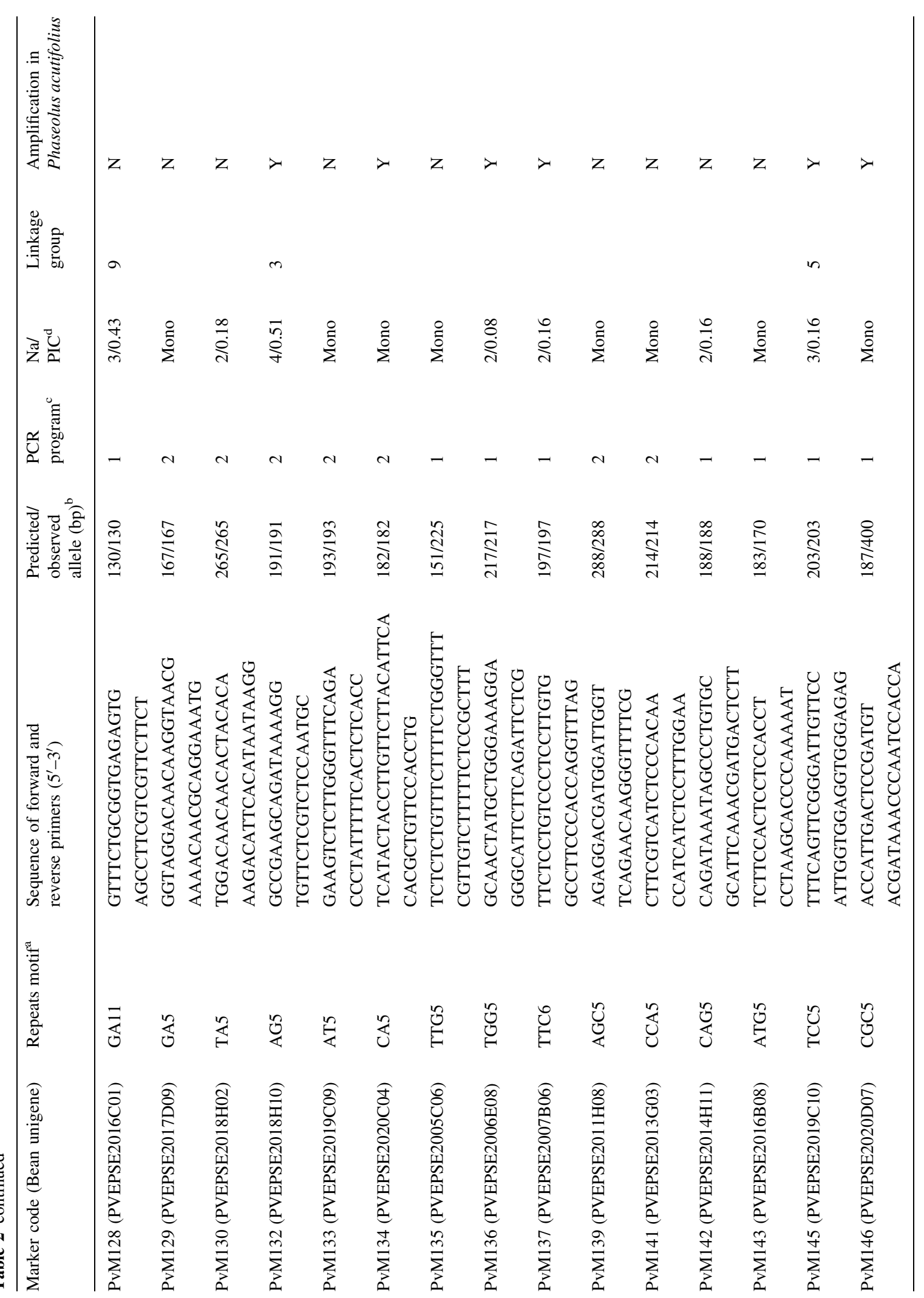




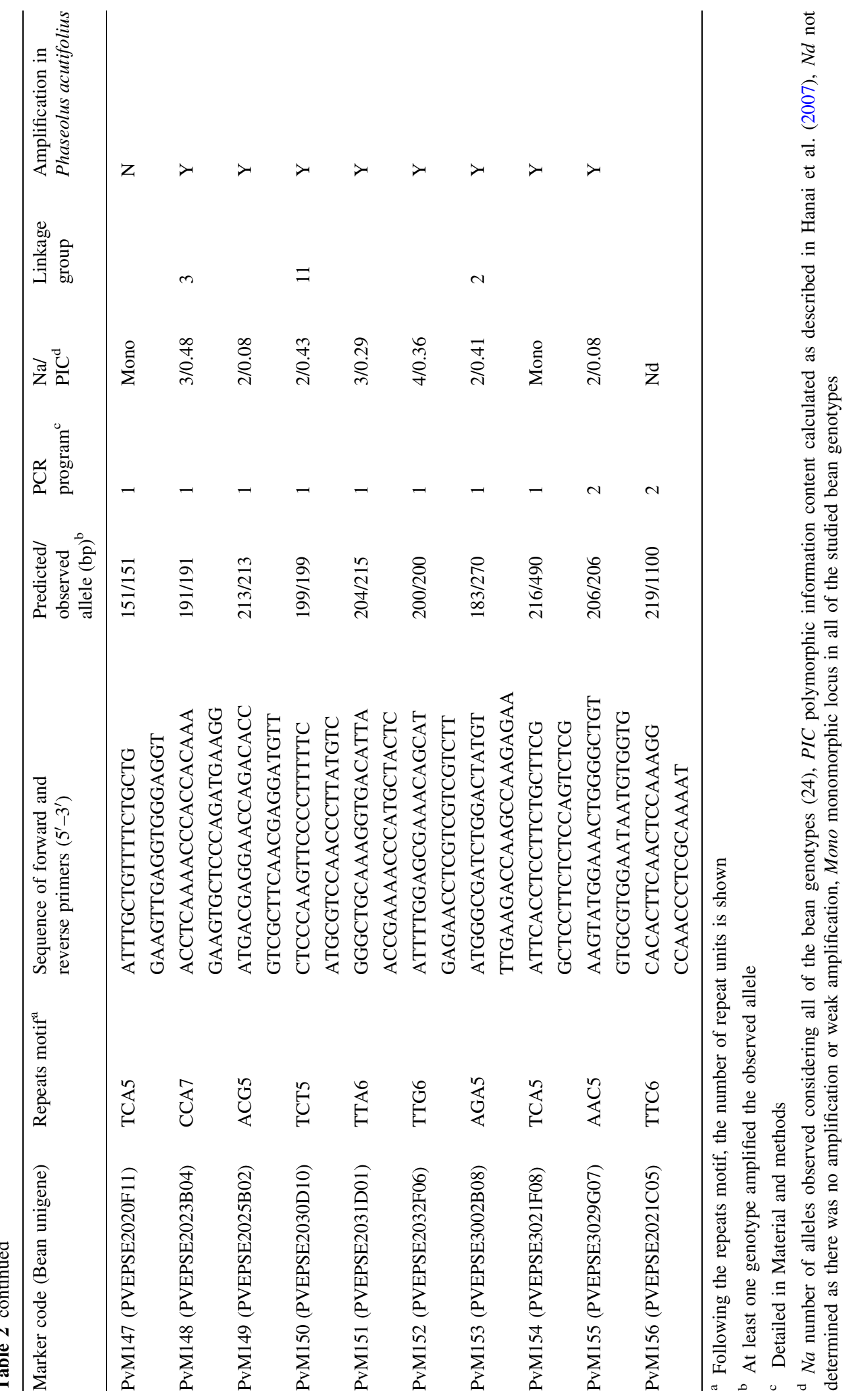


v. 3.0 (Lander et al. 1987). Segregation data here obtained (EST-SSR, RGA and AFLP markers) were merged with available data of markers placed on the framework of the core map (Freyre et al. 1998). Initially, three RFLP markers equally distant were anchored to their respective linkage group using the 'anchor' command. The 'assign' command (LOD > 3) was used to assign all other markers to the linkage groups. In each linkage group, the order of 10 highly informative markers was defined using the 'order' command. Then, the other markers were added to the map using the 'build' command (LOD > 2.0). Loci that could not be ordered with the default log-likelihood threshold value were referred to as accessory markers and placed in the most likely interval. The Kosambi mapping function was used for the calculation of map distances (Kosambi 1944). Map drawings were generated using MapChart (Voorrips 2002). The nomenclature and orientation of linkage groups followed the recent changes adopted by the Genetics Committee of the Bean Improvement Committee (Pedrosa-Harand et al. 2008).

\section{Results and discussion}

\section{Allelic variation at EST-SSR loci}

Out of 156 primer pairs designed initially, 139 amplified 140 loci of which 40 were analyzed previously (Hanai et al. 2007). The remaining 100 loci were evaluated in the present study using a set of bean genotypes (Table 2). About 13 amplicons were larger than expected, probably due to the presence of introns between primer sites. Nevertheless, only 11 EST-SSR loci presented a non-optimal amplification pattern and were not analyzed. A total of 89 pairs of primers amplified fragments that were easy to score, 54 of which revealed polymorphisms among the 24 bean genotypes. The number of alleles per polymorphic locus varied from 2 to 13 with an average of 2.7. The polymorphic information content (PIC) of the 54 loci ranged between 0.08 and 0.89 , with a mean PIC of 0.40 .

Our data agree with previous findings that reported an average of 2.9 (Yu et al. 1999) and 3.1 alleles per locus (Guerra-Sanz 2004) as both studies analyzed genic SSR in bean accessions. Generally, SSRs from anonymous sequences are regarded as more informative than SSRs of genic origin. For example, average values of six and seven alleles per locus were described by Gaitán-Solís et al. (2002) and Buso et al. (2006), respectively. The fact that expressed sequences are associated with biological processes and therefore are more conserved than anonymous ones could explain these differences; however, when the same set of bean genotypes were analyzed using SSR loci developed from genic and genomic sources, the results showed similar average values for PIC and number of alleles per locus between genic and genomic SSRs (Hanai et al. 2007).

A considerable number of polymorphic SSR loci is generally required for variety identification or even for pedigree analysis when polymorphisms are used for tracing parentage (Guerra-Sanz 2004). The locus PvM115 containing a CT motif repeated 25 times showed both higher PIC (0.89) and number of alleles (13) in the 24 genotypes analyzed (Fig. 1). In our previous study, 12 alleles were detected at the PvM21 locus (Hanai et al. 2007). Thus, these two EST-SSR loci are very informative and may be useful in both types of analyses.

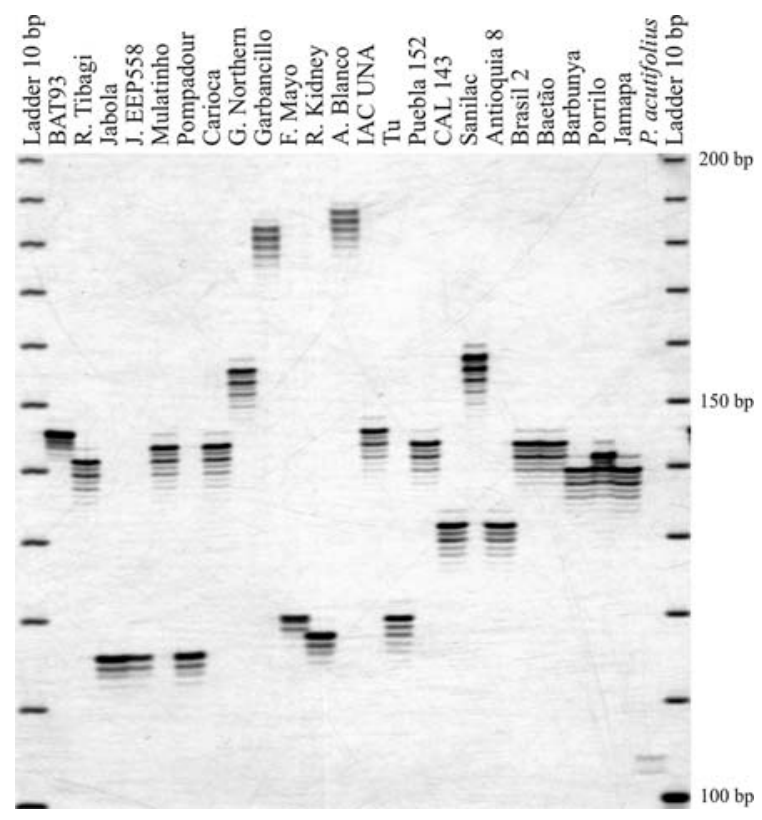

Fig. 1 Electrophoretic pattern at PvM115 locus (EST-SSR) in 24 Phaseolus genotypes detected in 6\% silver-stained polyacrylamide gel. 10-bp DNA ladder (Invitrogen) are in first and last lane 
An updated common bean core map

We screened 'BAT93' and 'Jalo EEP558' for polymorphisms using 156 EST-SSR primer pairs of the PvM series, 16 combinations of restriction enzymes (RsaI, HindIII, AluI and DraI) and NBS primers (Table 1) through the NBS-profiling methodology and 28 combinations of AFLP selective primers. A total of 140 EST-SSR primer pairs amplified scorable loci, of which 50 were polymorphic. Regarding the NBS-profiling method, the restriction enzyme RsaI was chosen because it generated better amplification profiles and more polymorphic RGA loci (data not shown). The four NBS primers in combination with $R s a$ I produced 194 loci, of which 32 were polymorphic (Fig. 2). In addition, the AFLP selective primer combinations (12 from EcoRI/MseI and 16 from PstI/ MseI digestions) amplified 1,252 loci, 29\% of them being polymorphic. From these, 15 combinations producing 203 polymorphic loci were selected for genotyping the mapping population (Table 3 ).
The merging of the data of the 285 loci developed in this study (50 EST-SSR, 32 RGA and 203 AFLP) with the data of 143 markers previously mapped into the core common bean linkage map (Freyre et al. 1998) resulted in a map comprised of 413 DNA markers (Table 4) distributed in 11 linkage groups (LG). About 15 markers remained unlinked. The length of the new linkage map was estimated at $1,259 \mathrm{cM}$, corresponding to an average of one marker per $3.0 \mathrm{cM}$. The number of markers per LG ranged from 32 (10) to 50 (8) while the LG lengths varied from 75 (5) to $147 \mathrm{cM}(2)$.

The levels of efficiency of both QTL mapping and selection based on DNA markers is enhanced when regularly spaced markers are available throughout the linkage groups (Lander and Botstein 1989). If the number of markers allocated to map positions is high, existing gaps are more likely to be saturated. With the integration of 282 new markers (50 EST-SSR, 32 RGA and 200 AFLP) into the common bean core map, we were able to place new markers in some
Fig. 2 Amplification pattern of RGA markers in $6 \%$ silver-stained polyacrylamide gel. The DNA was digested with $R s a \mathrm{I}$ and amplified using the primers AP and NBSaF. The parental lines are represented in duplicate ('BAT 93', lanes 1 and 2, and 'Jalo EEP558', lanes 3 and 4); lanes 6 through 35 correspond to $\mathrm{F}_{8}$ RILs. Arrows indicate polymorphic loci. Lane 5 shows the 25-pb DNA ladder (Invitrogen)

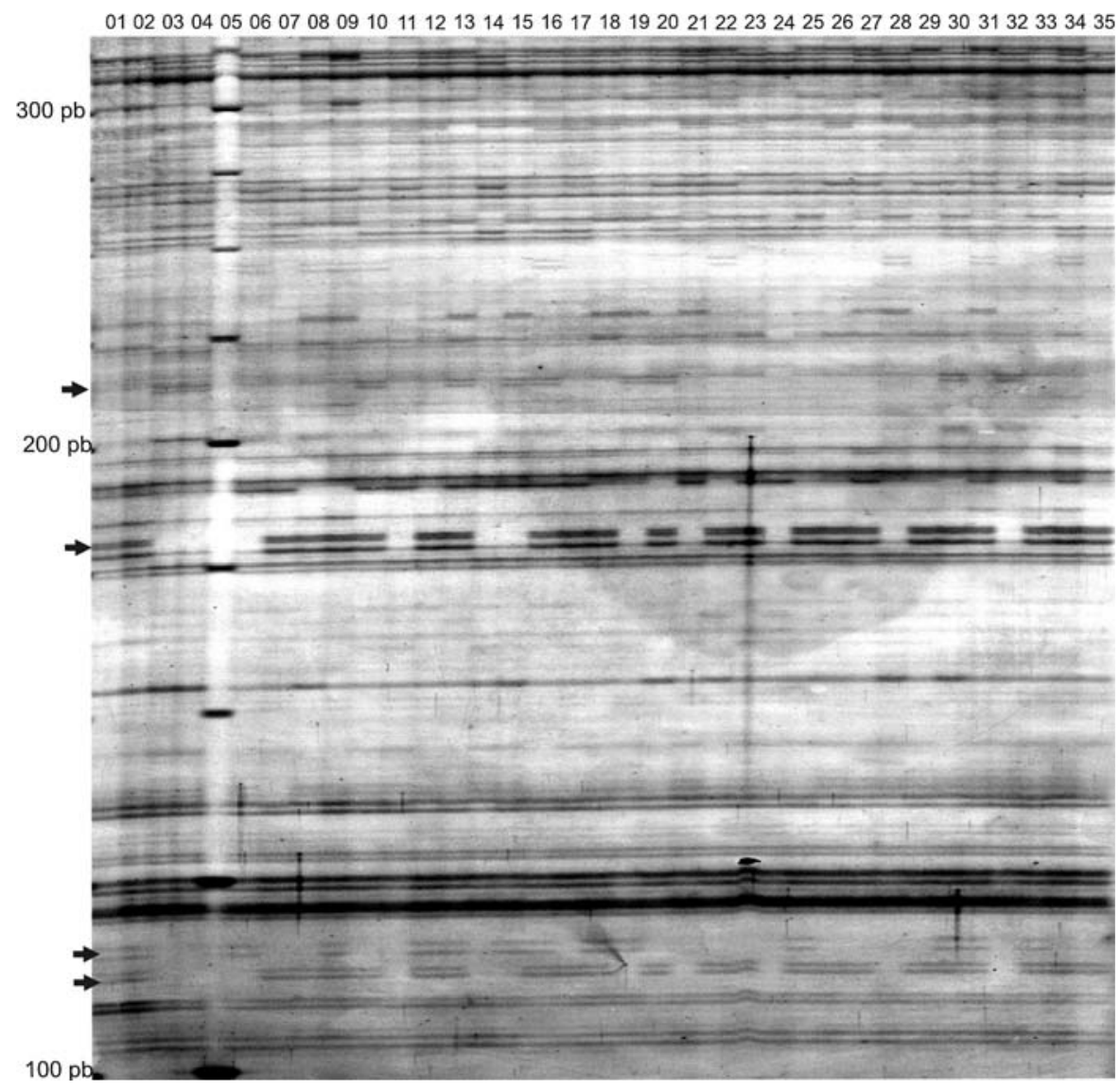


Table 3 Number of polymorphic loci per combination of AFLP primers

\begin{tabular}{lll}
\hline $\begin{array}{l}\text { Primer } \\
\text { combination }\end{array}$ & Selective nucleotides & $\begin{array}{l}\text { Number of } \\
\text { polymorphic loci }\end{array}$ \\
\hline P31M64 & P + AAA, M + GCT & 18 \\
P32M63 & P + AAC, M + GCA & 19 \\
P37M64 & P + ACG, M + GCT & 5 \\
P39M65 & $P+$ AGA, M + GGA & 8 \\
P39M63 & P + AGA, M + GCA & 11 \\
P38M65 & P + ACT, M + GGA & 4 \\
P32M64 & P + AAC, M + GCT & 6 \\
E31M48 & E + AAA, M + CAC & 20 \\
E39M49 & E + AGA, M + CAG & 10 \\
E40M56 & E + AGC, M + CGC & 23 \\
E37M60 & E + ACG, M + CTC & 23 \\
E31M60 & E + AAA, M + CTC & 18 \\
E40M49 & E + AGC, M + CAG & 8 \\
E31M49 & E + AAA, M + CAG & 18 \\
E39M48 & E + AGA, M + CAC & 12 \\
Total & & 203 \\
\hline
\end{tabular}

E EcoRI complementary primer, $P$ Pst I complementary primer, $M$ MseI complementary primer

existing gaps. In LG 3, for instance, five AFLP, one RGA, and one EST-SSR markers were positioned between markers Bng 12 and D1151 and in LG 6 three AFLP and one EST-SSR markers were positioned between markers ROF7a and D1086. Similarly, additional markers were placed in two linkage groups within regions where QTL for resistance to anthracnose were mapped before (Miklas et al. 2006b): the QTL interval $(40-75 \mathrm{cM})$ in LG 1 was saturated with seven AFLP and two EST-SSR markers whereas the QTL interval in LG 2 (65$95 \mathrm{cM}$ ) was saturated with 14 new markers, including 4 RGA (Fig. 3).

Slight discrepancies were observed between the present map and the previous one (Freyre et al. 1998). Linkage groups 2, 6 and 11 became shorter while LG 1, 3, 8, 9 and 10 became longer. These discrepancies are probably due to the size of the mapping population and the kind of markers used. In order to develop a core linkage map and align the existing RFLP maps, Freyre et al. (1998) used a number of markers with more missing data and a smaller population. For instance, the LG 2 of the Freyre's map had $175 \mathrm{cM}$ while the corresponding groups in the Florida and Davis' maps had 128 and $107 \mathrm{cM}$, respectively (Nodari et al. 1993a; Vallejos et al. 1992). In addition, the present map is about $30 \mathrm{cM}$ longer than the one reported by Freyre et al. (1998), because new markers were positioned at the end of the groups, e.g., LG 10 had eight new loci mapped as terminal markers, expanding its size to more than $36 \mathrm{cM}$ (Fig. 3).

\section{Segregation features}

Most of the markers (82.5\%) showed a 1:1 segregation ratio of the parental alleles $(P<0.05)$, as expected in a RIL population. Among the newly
Table 4 Distribution of different types of marker over the linkage groups (LG) of the novel common bean core map, and their lengths in centimorgans (cM)

a Markers previously assigned to the framework of the common bean integrated map (Freyre et al. 1998). EST-SSR expressed sequence tag derived single sequence repeats, $R G A$ resistance gene analog markers based on NBSprofiling method

\begin{tabular}{|c|c|c|c|c|c|c|}
\hline \multirow[t]{2}{*}{ LG } & \multirow{2}{*}{$\begin{array}{l}\text { No. of markers } \\
\text { previously mapped }^{\mathrm{a}}\end{array}$} & \multicolumn{3}{|c|}{ No. of novel markers } & \multirow[t]{2}{*}{ Total } & \multirow[t]{2}{*}{ Length $(\mathrm{cM})$} \\
\hline & & EST-SSR & RGA & AFLP & & \\
\hline 1 & 14 & 6 & 3 & 21 & 44 & 129.0 \\
\hline 2 & 15 & 6 & 4 & 14 & 39 & 146.7 \\
\hline 3 & 12 & 7 & 2 & 21 & 42 & 143.0 \\
\hline 4 & 8 & 1 & 3 & 23 & 35 & 99.6 \\
\hline 5 & 15 & 5 & 1 & 18 & 39 & 75.2 \\
\hline 6 & 15 & 2 & 0 & 16 & 33 & 97.1 \\
\hline 7 & 14 & 2 & 4 & 14 & 34 & 105.4 \\
\hline 8 & 11 & 7 & 4 & 28 & 50 & 146.1 \\
\hline 9 & 7 & 7 & 1 & 11 & 26 & 123.1 \\
\hline 10 & 9 & 4 & 5 & 14 & 32 & 108.4 \\
\hline 11 & 11 & 3 & 5 & 20 & 39 & 85.2 \\
\hline Total & 131 & 50 & 32 & 200 & 413 & 1258.8 \\
\hline
\end{tabular}



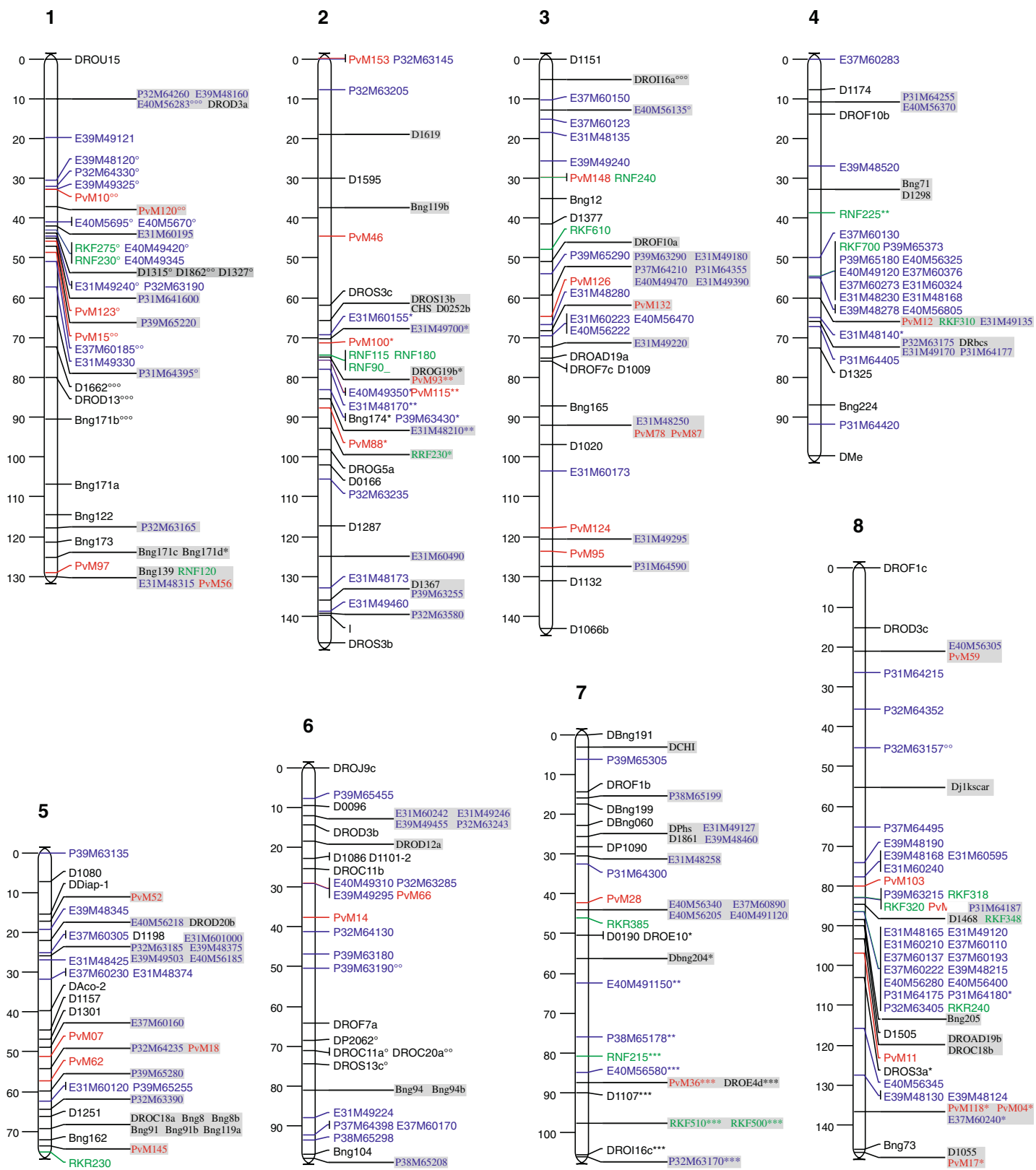

Fig. 3 An updated common bean molecular linkage map based on the 'BAT93' $\times$ 'Jalo EEP558' RIL population. The revised orientation and nomenclature of linkage groups follows that of the Bean Improvement Cooperative (http://www.css. msu.edu/bic/Genetics.cfm). About 261 markers were ordered with $\mathrm{LOD}>2.0$ and their distances $(\mathrm{cM})$ from top to bottom are indicated to the left of linkage groups $(L G)$. About 152 markers were assigned to linkage groups but not ordered in
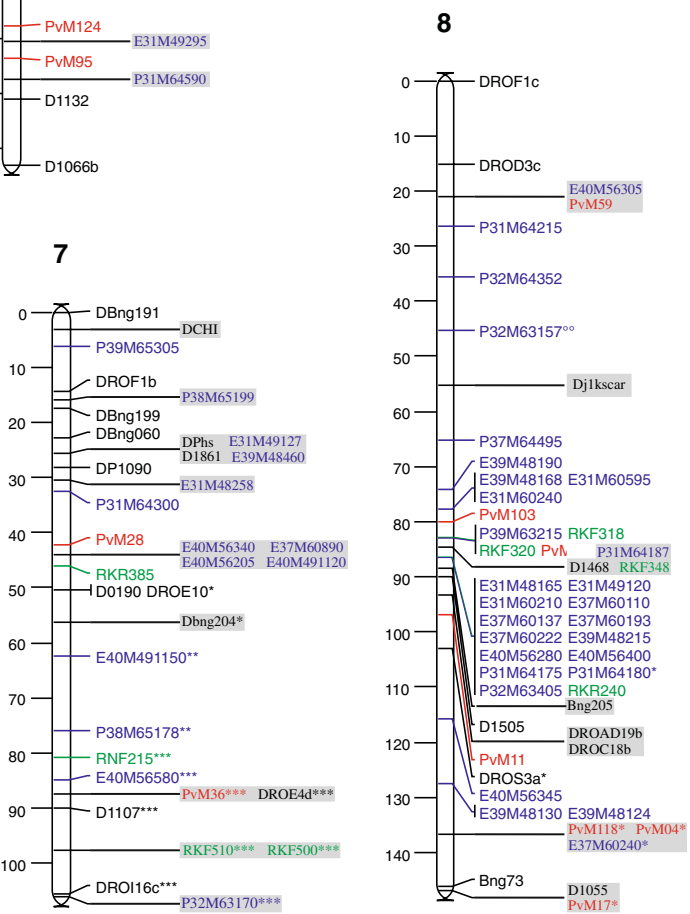

multipoint analyses (LOD $>2.0$ ) and were placed in the most likely interval (gray boxes) without changing the map distances. Loci with distorted segregation ratios are indicated by asterisks $(* P<0.05 ; * * P<0.01 ; * * * P<0.001$ for markers skewed toward 'BAT93') or degree symbols $\left({ }^{\circ} P<0.05\right.$; ${ }^{\circ} P<0.01 ;{ }^{\circ 0} P<0.001$ for markers skewed toward 'Jalo EEE558')

positioned markers, 13 EST-SSR (26\%), 7 RGA (22\%) and 28 AFLP (14\%) showed segregation distortion. Gametes in direct competition, meiotic

drive, and genes controlling pollen lethality are factors that affect allele segregation during meiosis and can produce distorted ratios (Moyle and Graham 

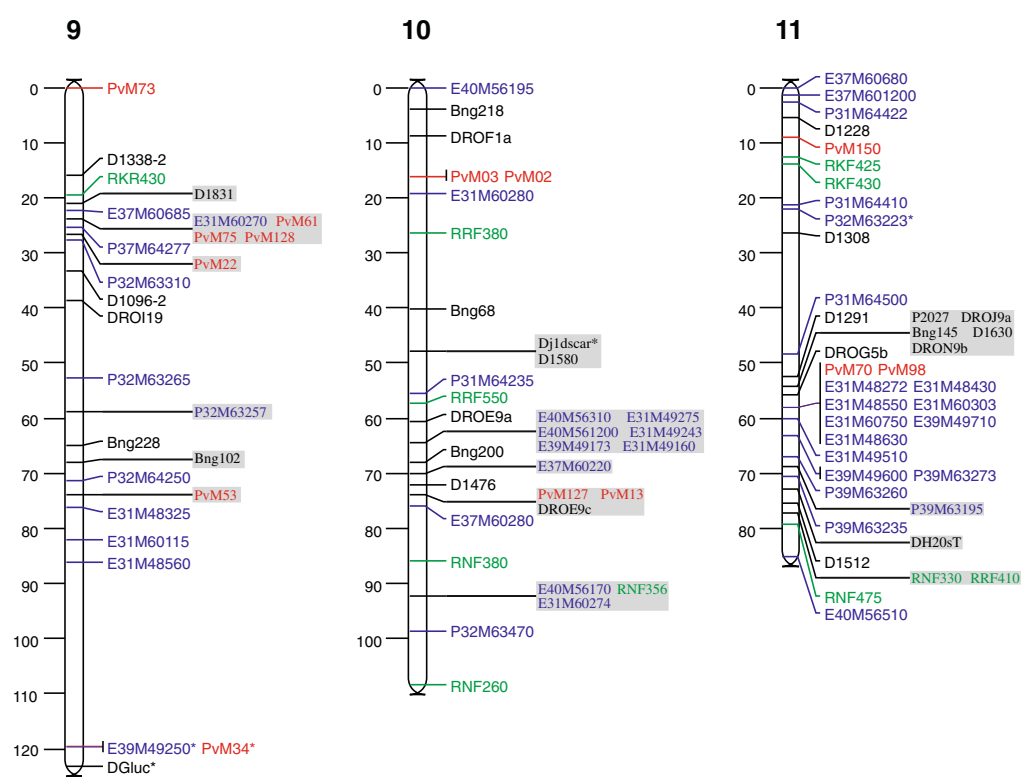

Fig. 3 continued

2006). Among the 28 AFLP loci with distorted segregation, similar numbers were found skewed towards 'BAT93' alleles (15) and 'Jalo EEP558' alleles (13). In contrast, segregation distortion affecting EST-SSR and RGA loci favored 'BAT93' alleles. Nine EST-SSR and five RGA loci showed an excess of 'BAT93' alleles, while four EST-SSR and two RGA loci showed an excess of 'Jalo EEP558' alleles. This could be explained by the higher adaptability of lines carrying 'BAT93' alleles. Since we used SSR markers that are within genes it is possible that their products were affected by natural selection leading to the observed bias in the segregation ratios. Following allelic frequencies of SSR loci in 24 generations, Rodrigues and dos Santos (2006) reported that all loci were affected by natural selection, which favored one of the parental common bean accessions ('Carioca MG') at 29 out of 30 loci.

Interestingly, markers showing distorted segregation were mainly located in six linkage groups. An excess of 'Jalo EEP558' alleles were positioned in two regions located on LG 1 and 6, while an excess of 'BAT93' alleles were mapped in four regions located in LG 2, 7, 8 and 9. The clustering of markers with segregation distortion possibly reflects the location of genes that were favored by either meiotic selection or inadvertent selection in BJ population.
Marker distribution

Table 4 shows the distribution of marker types in the common bean linkage groups together with group lengths (in cM). Non-anonymous EST-SSR and RGA markers were mapped to all linkage groups, excluding LG 6. About 50 EST-SSR markers were ordered with LOD $>2.0$ into 40 distinct positions of the 11 linkage groups of the BJ map. Although EST-SSR were positioned on all LGs, their distribution was not uniform and varied from one in LG 4 to seven markers in LG 3, LG 8 and LG 9 (Table 4). Interestingly, LG 4 is the group in which most of the microsatellites studied by $\mathrm{Yu}$ and coauthors were mapped ( $\mathrm{Yu}$ et al. 2000). This illustrates the complementariness of both studies regarding the saturation of the core map with SSR markers.

In general, we did not observe a direct relation between number of markers and length of the LGs. The shortest linkage group $(75 \mathrm{cM})$ had as many markers (39) as the largest one (123 cM), which contained 26 markers (Table 4). This could be explained by the clustering pattern in some regions of the bean genome. Using absolute co-segregation of three or more markers as a criterion for defining a cluster we inferred clustering in seven LGs: 1, 2, 3, 4, 6,8 and 11, with large clusters ( $>8$ markers) in 
groups 4, 8 and 11 (Fig. 3). AFLP markers formed the majority of the clusters. The uneven distribution of AFLP markers derived from double digestion with EcoRI and MseI was previously reported in other legume species such as soybean (Young et al. 1999) and adzuki bean (Vigna angularis; Han et al. 2005) but also in the yellow passion fruit (Lopes et al. 2006). The preferential localization of AFLP loci in DNA regions of recombination suppression may be associated with the restriction enzymes used, which may favor the finding of these markers in centromeric regions, for example (Troggio et al. 2007), as they may require methylation to maintain their specialized functions. Here, we used the combinations PstI with MseI and EcoRI with MseI, as suggested by Young et al. (1999). These authors proposed that PstI, which is blocked by methylation would be more efficient than EcoRI in producing AFLP markers placed at random on linkage maps. In fact, out of 51 PstI/MseIderived markers, only five were found completely linked, two being located in the cluster of LG 4 and three in the cluster of LG 8 .

Mapping markers with putative known function

Several EST-SSR showing similarities with known and unknown proteins were mapped in several linkage groups. These include markers with highly significant e-values $\left(<\mathrm{e}^{-30}\right)$ such as PvM61 (LG 9) from a sequence similar to members of the stressrelated NAC transcription factor family (Fang et al. 2008); PvM18 (LG 5) from a sequence similar to the leucine-rich repeat (LRR) domain of plant disease resistance genes (Ryan et al. 2007); and PvM87 (LG 3) from an EST similar to subtilisin-like proteases, a class of enzymes involved in recognition of pathogens and activation of defense responses (van der Hoorn and Jones 2004). A complete list of the putative function of ESTs from which SSR markers were developed in this work is presented in Table 5.

\section{Mapping of RGA markers}

About 32 RGA loci generated with the NBS-profiling method using four degenerated primers that target the NBS domain were mapped at 26 positions on 10 linkage groups (Fig. 3). The remaining six mapped at exactly the same loci (RKF275 and RNF230 on LG 1; RNF90, RNF115 and RNF180 on LG 2; RKF500 and
RKF510 on LG 7; RKF318 and RKF320 on LG 8; and RNF330 and RNF475 on LG 11). This was expected, as many disease resistance genes occur in clusters as complex loci in many plant species, including common bean. The anthracnose resistance locus Co-4 is such an example as it contains five copies of the COK-4 gene (Melotto et al. 2004). Vallejos et al. (2006) showed that multiple copies of a gene member of the TIR-NBS-LRR family were present within the $I$ locus, which confers resistance to Bean common mosaic virus.

At least five RGA markers mapped to regions containing resistance genes for anthracnose and rust diseases. In LG 1 the marker RNF120 co-located with Co-1, Co- $x$, Co-w and Ur-9 genes; in LG 7 the marker RKR385 was mapped near to Co-6 gene; and in LG 11 three markers (RNF330, RRF410 and RNF475) were positioned in the region containing the $\mathrm{Co}-2$ gene against anthracnose and $U r-3, U r-11$ and $U r$ Dorado genes against rust (Miklas et al. 2006a). The RGA markers were also positioned in the vicinity of QTLs located on the core map (Miklas et al. 2006a). For instance, markers RKF275 and RNF230 (LG 1) were mapped near to QTLs for resistance to common bacterial blight and white mold. In LG 2, the marker RRF230 was positioned in a region containing QTLs for resistance to common bacterial blight and anthracnose as well as RNF115, RNF180 and RNF90 co-located with a QTL for resistance to white mold. The RGA RNF240 mapped to a region that a QTL for resistance to Fusarium root rot was located in LG 3. The marker RKR230 (LG 5) was mapped together a QTL for resistance to white mold, and markers RKF500 and RKF510 (LG 7) co-positioned with a QTL conditioning common bacterial blight. The marker RRF550 (LG 10) was mapped near a QTL for resistance to angular leaf spot, and the markers RNF330, RRF410 and RNF475 (LG 11) were mapped near a QTL region for resistance to anthracnose (Miklas et al. 2006a).

About 16 RGA fragments were sequenced, and five sequences showed high similarity with plant resistance proteins (Table 5). The BLASTx analyses showed that RNF356 and RRF380 sequences are similar to resistance proteins from Glycine max. Similarly, sequences of RNF475 and RRF410 were highly similar to resistance proteins from $P$. vulgaris as well as the RNF330 sequence has similarity with a resistance protein from Medicago truncatula. Several 


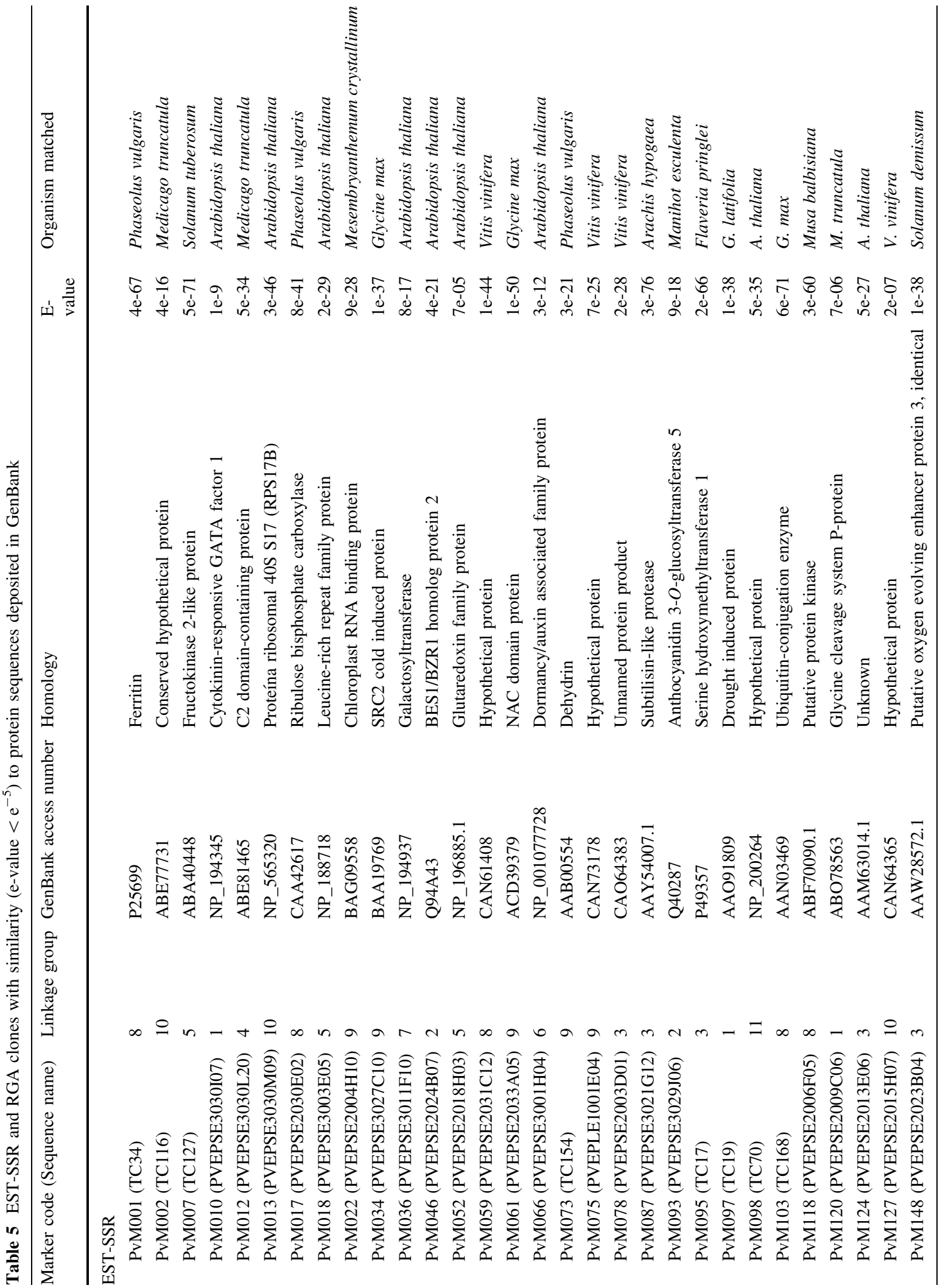


tagging approaches in candidate genes have been used for analyzing resistance genes in crop species, including common bean (López et al. 2003; Miklas et al. 2006b; Rivkin et al. 1999). Here we demonstrate the feasibility of NBS-profiling methodology for generating RGA loci as well as a complementary tool for tagging RGA that were not yet mapped in the common bean genome.

Acknowledgments Authors are in debt with the Brazilian institutions Fundação de Amparo à Pesquisa do Estado de São Paulo (FAPESP: grants 2004/13547-9 and 2008/54732-4 and scholarships 2004/07614-5 and 2008/52269-5), Conselho Nacional de Desenvolvimento Científico e Tecnológico (CNPq), and Coordenação de Aperfeiçoamento de Pessoal de Nível Superior (CAPES).

Open Access This article is distributed under the terms of the Creative Commons Attribution Noncommercial License which permits any noncommercial use, distribution, and reproduction in any medium, provided the original author(s) and source are credited.

\section{References}

Adam-Blondon AF, Sevignac M, Bannerot H, Dron M (1994) SCAR, RAPD and RFLP markers linked to a dominant gene (Are) conferring resistance to anthracnose in common bean. Theor Appl Genet 88:865-870

Altschul SF, Gish W, Miller W, Myers EW, Lipman DJ (1990) Basic local alignment search tool. J Mol Biol 215:403-410

Benchimol LL, de Campos T, Carbonell SAM, Colombo CA, Chioratto AF, Formighieri EF, Gouvea LRL, de Souza AP (2007) Structure of genetic diversity among common bean (Phaseolus vulgaris L.) varieties of Mesoamerican and Andean origins using new developed microsatellite markers. Genet Resour Crop Evol 54:1747-1762

Blair MW, Pedraza F, Buendia HF, Gaitan-Solis E, Beebe SE, Gepts P, Tohme J (2003) Development of a genome-wide anchored microsatellite map for common bean (Phaseolus vulgaris L.). Theor Appl Genet 107:1362-1374

Broughton WJ, Hernandez G, Blair M, Beebe S, Gepts P, Vanderleyden J (2003) Beans (Phaseolus spp.)—model food legumes. Plant Soil 252:55-128

Brugmans B, Wouters D, van Os H, Hutten R, van der Linden G, Visser R, van Eck H, van der Vossen E (2008) Genetic mapping and transcription analyses of resistance gene loci in potato using NBS profiling. Theor Appl Genet 117:1379-1388

Buso GSC, Amaral ZPS, Brondani RPV, Ferreira ME (2006) Microsatellite markers for the common bean Phaseolus vulgaris. Mol Ecol Notes 6:252-254

Caixeta ET, Borém A, Kelly JD (2005) Development of microsatellite markers based on BAC common bean clones. Crop Breed Appl Biotechnol 5:125-133 
Campos T, Benchimol LL, Carbonell SAM, Chioratto AF, Formighieri EF, de Souza AP (2007) Microsatellites for genetic studies and breeding programs in common bean. Pesqui Agropecu Bras 42:589-592

Cardoso JMK, Oblessuc PR, de Campos T, Sforça DA, Carbonell SAM, Chioratto AF, Formighieri EF, de Souza AP, Benchimol LL (2008) New microsatellite markers developed from an enriched microsatellite common bean library. Pesqui Agropecu Bras 43:929-936

Creste S, Tulmann-Neto A, Figueira A (2001) Detection of single sequence repeat polymorphisms in denaturing polyacrylamide sequencing gels by silver staining. Plant Mol Biol Report 19:1-8

Doyle JJ, Doyle JL (1987) A rapid DNA isolation procedure to small amounts of fresh leaf tissue. Phytochem Bull 19:1115

Fang Y, You J, Xie K, Xie W, Xiong L (2008) Systematic sequence analysis and identification of tissue-specific or stress-responsive genes of NAC transcription factor family in rice. Mol Genet Genomics 280:547-563

Ferrier-Cana E, Geffroy V, Macadre C, Creusot F, ImbertBollore P, Sevignac M, Langin T (2003) Characterization of expressed NBS-LRR resistance gene candidates from common bean. Theor Appl Genet 106:251-261

Flandez-Galvez H, Ades PK, Ford R, Pang ECK, Taylor PWJ (2003) QTL analysis for ascochyta blight resistance in an intraspecific population of chickpea (Cicer arietinum L.). Theor Appl Genet 107:1257-1265

Freyre R, Skroch PW, Geffroy V et al (1998) Towards an integrated linkage map of common bean. 4. Development of a core linkage map and alignment of RFLP. Theor Appl Genet 97:847-856

Gaitán-Solís E, Duque MC, Edwards KJ, Tohme J (2002) Microsatellite repeats in common bean (Phaseolus vulgaris): isolation, characterization, and cross-species amplification in Phaseolus ssp. Crop Sci 42:2128-2136

Gepts P (1998) Origin and evolution of common bean: past events and recent trends. Hortscience 33:1124-1130

Grisi MCM, Blair MW, Gepts P, Brondani C, Pereira PAA, Brondani RPV (2007) Genetic mapping of a new set of microsatellite markers in a reference common bean (Phaseolus vulgaris) population BAT93 $\times$ Jalo EEP558. Genet Mol Res 6:691-706

Guerra-Sanz JM (2004) New SSR markers of Phaseolus vulgaris from sequence databases. Plant Breed 123:87-89

Han OK, Kaga A, Isemura T, Wang XW, Tomooka N, Vaughan DA (2005) A genetic linkage map for azuki bean [Vigna angularis (Willd.) Ohwi \& Ohashi]. Theor Appl Genet 111:1278-1287

Hanai LR, Campos T, Camargo LEA, Benchimol LL, de Souza AP, Melotto M, Carbonell SAM, Chioratto AF, Consoli L, Formighieri EF, Siqueira M, Tsai SM, Vieira MLC (2007) Development, characterization, and comparative analysis of polymorphism at common bean SSR loci isolated from genic and genomic sources. Genome 50:266-277

Jarne P, Lagoda PJL (1996) Microsatellites, from molecules to populations and back. Trends Ecol Evol 11:424-429

Kanazin V, Marek LF, Shoemaker RC (1996) Resistance gene analogs are conserved and clustered in soybean. Proc Natl Acad Sci USA 93:11746-11750
Koinange EMK, Singh SP, Gepts P (1996) Genetic control of the domestication syndrome in common bean. Crop Sci 36:1037-1045

Kosambi DD (1944) The estimation of map distance from recombination values. Annu Eugenetics 12:172-175

Lander ES, Botstein D (1989) Mapping mendelian factors underlying quantitative traits using RFLP linkage maps. Genet 121:185-199

Lander E, Green P, Abrahamson J, Barlon A, Daley M, Lincoln S, Newburg L (1987) MAPMAKER: an interactive computer package for constructing primary genetic linkages maps of experimental and natural populations. Genomics 1:174-181

Li YC, Korol AB, Fahima T, Nevo E (2004) Microsatellites within genes: structure, function, and evolution. Mol Biol Evol 21:991-1007

Lopes R, Lopes MTG, Carneiro MS, Pina Matta F, Camargo LEA, Vieira MLC (2006) Linkage and mapping of resistance genes to Xanthomonas axonopodis pv. passiflorae in yellow passion fruit. Genome 49:17-29

López CE, Acosta IF, Jara C, Pedraza F, Gaitan-Solis E, Gallego G, Beebe S, Tohme J (2003) Identifying resistance gene analogs associated with resistances to different pathogens in common bean. Phytopathology 93:88-95

Melotto M, Coelho M, Pedrosa-Harand A, Kelly J, Camargo LEA (2004) The anthracnose resistance locus Co-4 of common bean is located on chromosome 3 and contains putative disease resistance-related genes. Theor Appl Genet 109:690-699

Métais I, Hamon B, Jalouzot R, Peltier D (2002) Structure and level of genetic diversity in various bean types evidenced with microsatellite markers isolated from a genomic enriched library. Theor Appl Genet 104:1346-1352

Miklas PN, Coyne DP, Grafton KF, Mutlu N, Reiser J, Lindgren DT, Singh SP (2003) A major QTL for common bacterial blight resistance derives from the common bean great northern landrace cultivar Montana No. 5. Euphytica 131:137-146

Miklas PN, Kelly J, Beebe S, Blair M (2006a) Common bean breeding for resistance against biotic and abiotic stresses: from classical to MAS breeding. Euphytica 147:105-131

Miklas PN, Hu JG, Grunwald NJ, Larsen KM (2006b) Potential application of TRAP (targeted region amplified polymorphism) markers for mapping and tagging disease resistance traits in common bean. Crop Sci 46:910-916

Moyle LC, Graham EB (2006) Genome-wide associations between hybrid sterility QTL and marker transmission ratio distortion. Mol Biol Evol 23:973-980

Murray J, Larsen J, Michaels TE, Schaafsma A, Vallejos CE, Pauls KP (2002) Identification of putative genes in bean (Phaseolus vulgaris) genomic (Bng) RFLP clones and their conversion to STSs. Genome 45:1013-1024

Mutlu N, Miklas PN, Coyne DP (2006) Resistance gene analog polymorphism (RGAP) markers co-localize with disease resistance genes and QTL in common bean. Mol Breed 17:127-135

Nodari RO, Tsai SM, Gilbertson RL, Gepts P (1993a) Towards an integrated linkage map of common bean. 2. Development of an RFLP-based linkage map. Theor Appl Genet $85: 513-520$ 
Nodari RO, Tsai SM, Guzmán P, Gilbertson RL, Gepts P (1993b) Towards an integrated linkage map of common bean. 3. Mapping genetic factors controlling host-bacteria interactions. Genetics 134:341-350

Oliveira EJ, Pádua JG, Zucchi MI, Vencovsky R, Vieira MLC (2006) Origin, evolution and genome distribution of microsatellites. Genet Mol Biol 29:294-307

Pedrosa-Harand A, Porch T, Gepts P (2008) Standard nomenclature for common bean chromosomes and linkage groups. Annu. Rept. Bean Improv. Coop. 51:106-107. http://www.css.msu.edu/bic/PDF/Standardized Genetic \& Physical Bean Map 2008.pdf

Rivkin MI, Vallejos CE, McClean PE (1999) Disease-resistance related sequences in common bean. Genome 42:41-47

Rodrigues TB, dos Santos JB (2006) Effect of natural selection on common bean (Phaseolus vulgaris) microsatellite alleles. Genet Mol Biol 29:345-352

Ryan CA, Huffaker A, Yamaguchi Y (2007) New insights into innate immunity in Arabidopsis. Cell Microbiol 9:19021908

Sanger F, Nicklen S, Coulson AR (1977) DNA sequencing with chain-terminating inhibitors. Proc Natl Acad Sci USA 74:5463-5467

Timmerman-Vaughan GM, Frew TJ, Russell AC, Khan T, Butler R, Gilpin M, Murray S, Falloon K (2002) QTL mapping of partial resistance to field epidemics of ascochyta blight of pea. Crop Sci 42:2100-2111

Troggio M, Malacarne G, Coppola G, Segala C, Cartwright DA, Pindo M, Stefanini M, Mank R, Moroldo M, Morgante M, Grando MS, Velasco R (2007) A dense singlenucleotide polymorphism-based genetic linkage map of grapevine (Vitis vinifera L.) anchoring pinot noir bacterial artificial chromosome contigs. Genetics 176:2637-2650

Vallejos CE, Sakiyama NS, Chase CD (1992) A molecular marker-based linkage map of Phaseolus-vulgaris L. Genetics 131:733-740
Vallejos CE, Astua-Monge G, Jones V, Plyler TR, Sakiyama NS, Mackenzie SA (2006) Genetic and molecular characterization of the I locus of Phaseolus vulgaris. Genetics 172:1229-1242

van der Hoorn RAL, Jones JD (2004) The plant proteolytic machinery and its role in defense. Curr Opin Plant Biol 7:400-407

van der Linden CG, Wouters DCAE, Mihalka V, Kochieva EZ, Smulders MJM, Vosman B (2004) Efficient targeting of plant disease resistance loci using NBS profiling. Theor Appl Genet 109:384-393

Voorrips RE (2002) MapChart: software for the graphical presentation of linkage maps and QTLs. J. Heredity 93:77-78

Vos P, Hogers R, Bleeker M, Reijans M, Vandelee T, Hornes M, Frijters A, Pot J, Peleman J, Kuiper M, Zabeau M (1995) AFLP - a new technique for DNA-fingerprinting. Nucleic Acids Res 23:4407-4414

Yaish MWF, Pérez de la Vega M (2003) Isolation of (GA)n microsatellite sequences and description of a predicted MADS-box sequence isolated from common bean (Phaseolus vulgaris L.). Genet Mol Biol 26:337-342

Young WP, Schupp JM, Keim P (1999) DNA methylation and AFLP marker distribution in the soybean genome. Theor Appl Genet 99:785-792

Yu ZH, Stall RE, Vallejos CE (1998) Detection of genes for resistance to common bacterial blight of beans. Crop Sci 38:1290-1296

Yu K, Park SJ, Poysa V (1999) Abundance and variation of microsatellite DNA sequences in beans (Phaseolus and Vigna). Genome 42:27-34

Yu K, Park SJ, Poysa V, Gepts P (2000) Integration of simple sequence repeat (SSR) markers into a molecular linkage map of common bean (Phaseolus vulgaris L.). J Heredity 91:429-434 